\title{
O PERSPECTIVĂ INVERSĂ DE PE CEALALTĂ PARTE A GLOBULUI
}

Asist. dr. arh. Ioana Ardelean

ioana_c_ardelean@yahoo.com

INJE UNIVERSITY

GIMHAE, COREEA DE SUD

09/2019-07/2020

\#DESIGN INTEGRAT \#MULTIDISCIPLINAR \#WELL-BEING \#SPATII MEDICALE \#DESIGN MEDICAL 


\section{CONTEXT}

Coreea este o țară impresionantă în multe sensuri și desigur, prin prisma culturii asiatice, foarte diferită de cultura europeană. Prima impresie nu poate fi detașată de infrastructura avansată și omniprezentă în teritoriu, atât pe uscat cât și pe mare. Teritoriul țării este efectiv împânzit de munți, nu foarte înalți dar deși, iar orașele, foarte întinse și ele, se dezvoltă numai în văi, între acești munți, pe care uneori îi înglobează în structura urbană însă nu îi afectează antropic. Restul zonelor plate sunt ocupate intensiv cu sere care produc 365 de zile pe an, indiferent de sezon sau de intemperii (Fig. 1,2). Acestea sunt puternice în perioada taifunurilor, din iulie și pana în octombrie, însă nu par să mai reprezinte provocări insurmontabile pentru coreeni. De altfel este impresionant modul în care cultura coreeană se raportează la natură și sensibilitatea cu care operează în proiectele peisagere sau unele amenajări ale teritoriului (Fig. 3,4,5). Peisajul coreean este frumos și poetic, iar moștenirea culturii animiste și budiste și-a lăsat amprenta asupra locurilor și atitudinii oamenilor.
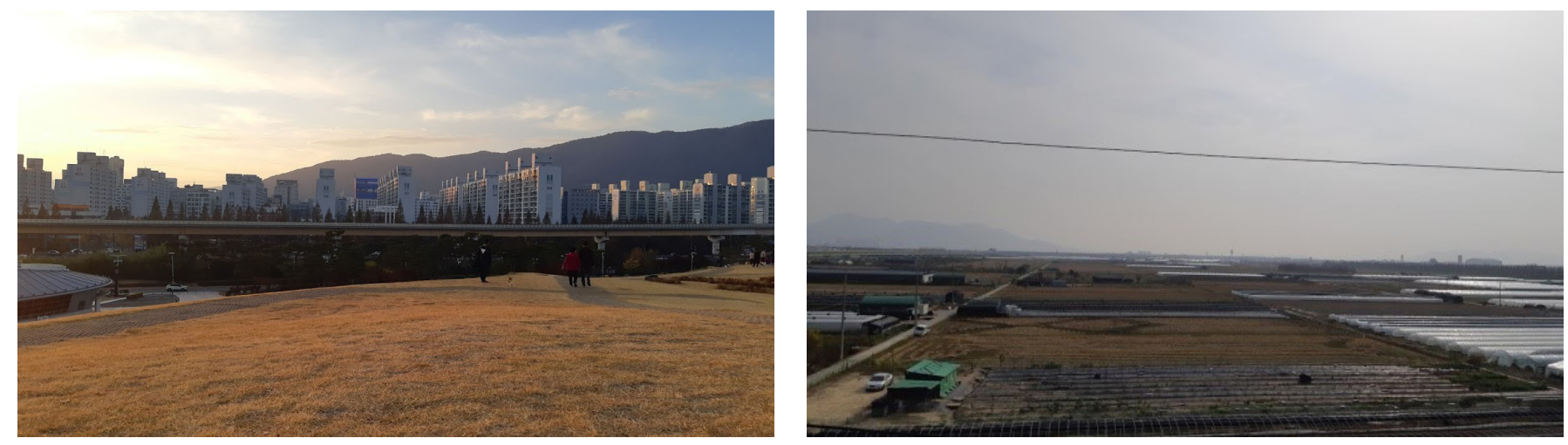

Fig. 1, 2. Infrastructură și teritoriu.

Coreea are un avantaj în teritoriu și anume densitatea mare a populației într-o peninsulă relativ mică, iar asta îi face pe coreeni extrem de eficienți și pragmatici. De asemenea, ca popor sunt foarte perseverenți și determinați. Aceasta este și atitudinea care răzbate din interacțiunea cu mulți colegi arhitecți, profesori și studenți. 

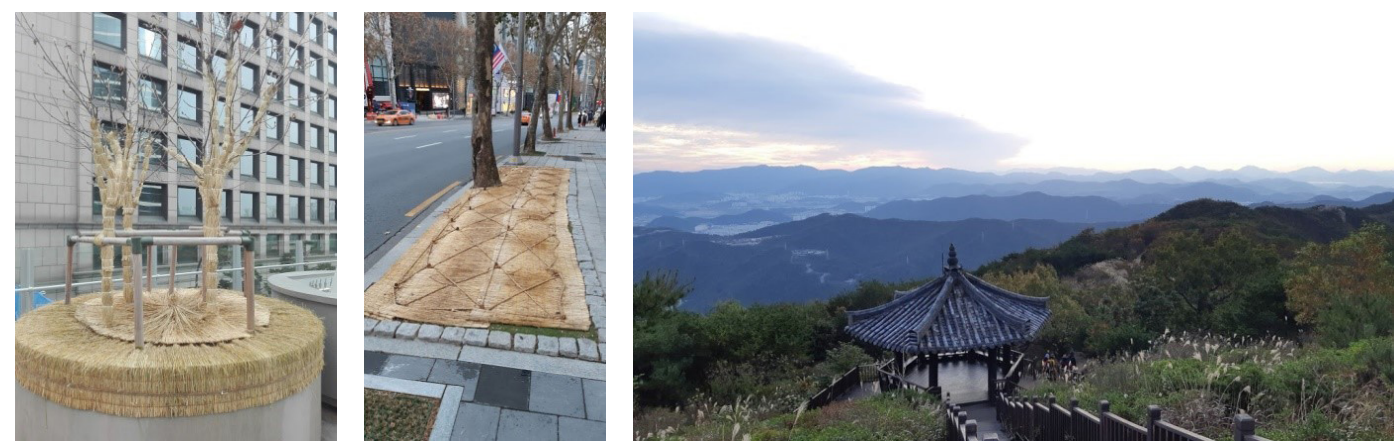

Fig. 3, 4, 5. Pregătirea plantelor din spațiile urbane pentru iarnă și peisaj tipic coreean, vedere de pe unul din munții din orașul Gimhae.

\section{VIATTA UNIVERSITARĂ}

Universitatea Inje are un campus în orașul Gimhae, un fel de satelit al metropolei Busan, respectiv al doilea oraș al țării, și un campus în Seoul. Viața universitară într-un campus are avantajul unui adevărat furnicar, fervoarea și energia comunității studențești și a celei profesorale dar și dezavantajul izolării și deconectării de la ritmul metropolei. Organizarea și funcționarea universității au fost făcute inițial după modelul american. în mediul academic în care am activat este un flux constant de profesori cu cariere internaționale, care sunt invitați să predea, să țină conferințe și workshop-uri. Aceasta compensează faptul că programe de mobilități pentru studenți, de talia și la scara Erasmus, nu există în Asia. Studenții la arhitectură, spre exemplu, pot să plece în practică după anul III de studiu la birouri internaționale, iar preferințele lor sunt îndreptate tot către SUA.

Cu toate acestea, din discuțiile cu colegii coreeni reiese că în ultimii ani universitățile au început să-și îndrepte atenția spre modelul european și doresc să-și completeze experiența cu stilul de abordare european. De altfel, am avut ocazia, să particip în cadrul departamentului la conferințe internaționale și workshop-uri susținute împreună cu profesori invitați din SUA - Arizona State University, Spania - A Coruna University și Cehia - Masarik University.

Această atitudine se reflectă cumva și la nivelul breslei și al specialiștilor implicați în proiectarea spațiilor urbane: modelul urbanismului european, atractivitatea spațiilor publice specifică orașelor europene face parte din strategia de upgrade a orașului asiatic. Acest fapt răzbate din programul Colegiului Arhitecților din Coreea, din expozițiile multidisciplinare sau excursiile de studii organizate în Europa, din proiectele inspirate din exemplele de succes ale Barcelonei sau ale altor orașe de referință. 
Am remarcat, de asemenea, deschiderea universității către public și către societate, munca studenților și a profesorilor materializându-se imediat în expoziții găzduite în spațiile expoziționale din oraș, adresate unui public larg, nu doar celui de specialitate. În fiecare oraș am întâlnit câte un centru expozițional sau câte un centru de design reprezentativ, care asigură această interfață necesară între specialiști și publicul larg.

În Coreea nici un cadru didactic nu poate practica sau deține alt job în afara normei didactice, ca atare nici arhitecții nu pot profesa în perioada în care sunt implicați în viața academică.

Anul universitar presupune două semestre a câte 15 săptămâni de activitate efectivă, semestrul I din martie până în iulie și semestrul II din septembrie până în decembrie. Între semestre, studenții masteranzi și doctoranzi își continuă activitatea pentru 8h/ zi, în cadrul atelierelor amenajate în facultate. Studenții, deși locuiesc în campus, își desfășoară activitatea în ateliere unde au instalate posturi de lucru (desktop-uri, monitoare, etc) iar accesul în clădiri este liber 24h/zi. Ca atare, există perioade în care studenții își instalează și locuri de dormit în atelier, iar noaptea se pot zări cu ușurință lumini în diverse clădiri ale campusului, altele decât dormitoarele.

\section{ACTIVITATEA DIDACTICĂ}

În urma aplicației și procesului de selecție deschise public de Universitatea Inje am ocupat postul de Adjunct Professor în cadrul U_Integrated Design Department, Design College.

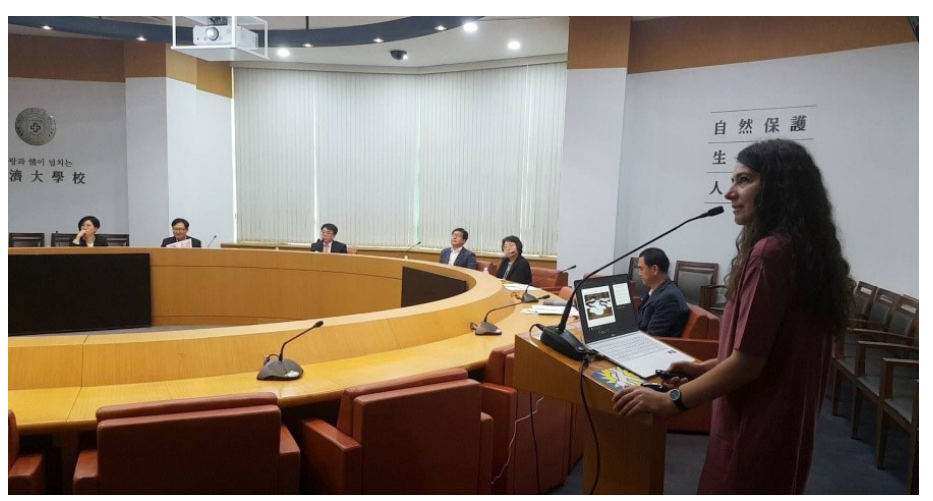

Fig. 6. Prezentarea în fața președintelui prof. dr. Jeon Minhyon și conducerii Universității Inje.
Recomandarea pentru aplicație am primit-o în cadrul UAUIM, prin atelierul de proiectare la care activez, iar procesul de selecție s-a realizat pe baza concursului de dosare depuse conform procedurilor internaționale, ca răspuns al aplicației. În cazul meu, aveam să aflu mai târziu, un plus l-a reprezentat experiența practică în design. Motivația mea a fost provocarea pe care o ridică o astfel de experiență pe cealaltă parte a globului, și perspectiva pe care o poți construi asupra propriei deveniri și asupra mediului din care provii, nu în ultimul rând o perspectivă din direcție inversă asupra culturii europene de care mă simt puternic atașată. Distanța și timpul petrecut în Coreea mi- 
au oferit un filtru de privire obiectiv și, bineînțeles, oportunitatea experimentării unei lumi complet diferite și fascinante.

Anul universitar a debutat pentru mine prin prezentarea profilului, a pregătirii și formării mele din UAUIM și a universității noastre, susținută în fata președintelui, conducerii universității și conducerii facultății (Fig. 6)

\section{DEPARTAMENTUL ȘI ACTIVITĂȚILE SPECIFICE}

U_Integrated Design Department: U este acronimul de la ubiquitous/omniprezent, iar pentru o perioadă de 5 ani, conform unei strategii guvernamentale (deși vorbim de o universitate privată), subiectul de lucru și de cercetare pentru acest departament sunt spațiile și serviciile medicale. La fiecare 5 ani sau la alte intervale - în funcție de priorități, acest subiect se poate continua sau schimba, iar odată cu aceasta se schimbă și numele departamentului.

După cum sugerează denumirea departamentului, aspectul cel mai interesant este designul integrat: de la proiectarea și configurarea spațiului până la designul echipamentelor sau obiectelor medicale, de la analiza și designul fluxurilor funcționale până la signalistică sau grafica broșurilor și cărților de profil.

Este foarte convingătoare această viziune aplicată și pragmatică pe care o urmăresc instituțiile coreene și care reflectă atenția și strategia față de provocările societății, orientare către viitor, cât și faptul că prin această viziune reușesc să-și exploateze și săși dezvolte potențialul.

Norma didactică pe care am efectuat-o ca Adjunct Professor a făcut parte din programul de master al Colegiului, și dat fiind subiectul spațiilor și serviciilor medicale a reunit în aceeași grupă, studenți provenind din specializări diferite: arhitectură, arhitectură de interior, design de produs, design vizual, design media. Astfel, pe parcursul unui întreg an universitar am fost titular al următoarelor discipline:

- atelier de proiectare și design (program master): Future Content Design - Semestrul I

- curs master: Universal Space Design, Semestrul I

- curs master: Users Analysis - Semestrul II

- curs master: Healthcare Space Design - Semestrul II

De asemenea, am activat ca asistent în cadrul atelierului de proiectare de arhitectură al anului III de studiu, pe durata unui semestru, atelier îndrumat de conf. dr. arh. Dan Dinoiu, de la UAUIM. 
Activitatea didactică a fost dublată de cea de cercetare, fiind integrată în proiectele și echipele de cercetare existente, iar această activitate s-a materializat prin trei articole publicate pe parcursul întregului an.

\section{ATELIERUL DE ARHITECTURĂ}

Atelierele de arhitectură și design se desfășoară în mod similar celor de la noi, grupele sunt foarte mici, au în jur de 10-12 studenți, iar acesta este un avantaj clar în relația dintre îndrumător și student. Studenții petrec mult timp din cursul zilei în atelier, unde lucrează, dat fiind că au instalate posturi de lucru permanente direct în atelier. Întâlnirea cu îndrumătorul atelierului are loc o dată pe săptămână, dar se poate face și de doua ori în funcție de decizia îndrumătorului. Toți studenții participă la corecturi în jurul mesei de lucru extinse (Fig. 7).

Un singur proiect este dezvoltat pe parcursul întregului semestru (15 săptămâni) iar jurizarea se face în două faze, în comun între 3 ateliere: o jurizare intermediară după 4-5 săptămâni, pentru analiză și concept (Fig. 8), și jurizarea finală.

În anul III de studiu temele de proiect au fost, următoarele: locuințe colective în semestrul I și muzeu de artă în semestrul II, iar in anul IV, semestrul I - azil pentru vârstnici.

În ciuda barierelor de limba, a timidității în relația cu profesorii (mai ales cu cei străini), la care contribuie și normele culturale coreene, studenții la arhitectură sunt foarte determinați și perseverenți. Principala provocare este însă aceea de a te adapta stilului lor și de a dezvolta niște referințe comune în procesul de îndrumare, pentru că background-ul lor este cumva necunoscut într-o prima fază. Spre exemplu, noțiunea de spațiu public este inexistentă în cultura coreeană. Cu toate acestea, din proiectele lor răzbate faptul că sunt bine pregătiți, că știu și înțeleg să dezvolte spațiile dintre funcțiuni și din afara clădirilor, dar că trebuie mereu să le numească: stradă, alee, promenadă, foyer, lobby etc. Este, din punctul meu de vedere, o perspectivă interesantă de lucru, pentru că spațiul public nu e omogen, nu are aceeași intensitate, iar termenul în sine trimite la un concept generic. A-I numi înseamnă a-l califica dar există și pericolul unei super-programări ce nu mai lasă loc emergenței.

Cel mai impresionant aspect despre studenții coreeni ai anului III de studiu cu care am avut ocazia să interacționez la atelierul de arhitectură și la jurizări, este claritatea și fluența demersului și sensibilitatea de care dau dovadă în analiza sitului și în abordare. Sunt în stare să observe situl printr-un filtru personal absolut impresionant, să abstractizeze această sensibilitate într-o idee cu care știu apoi să opereze controlat pas cu pas până la 

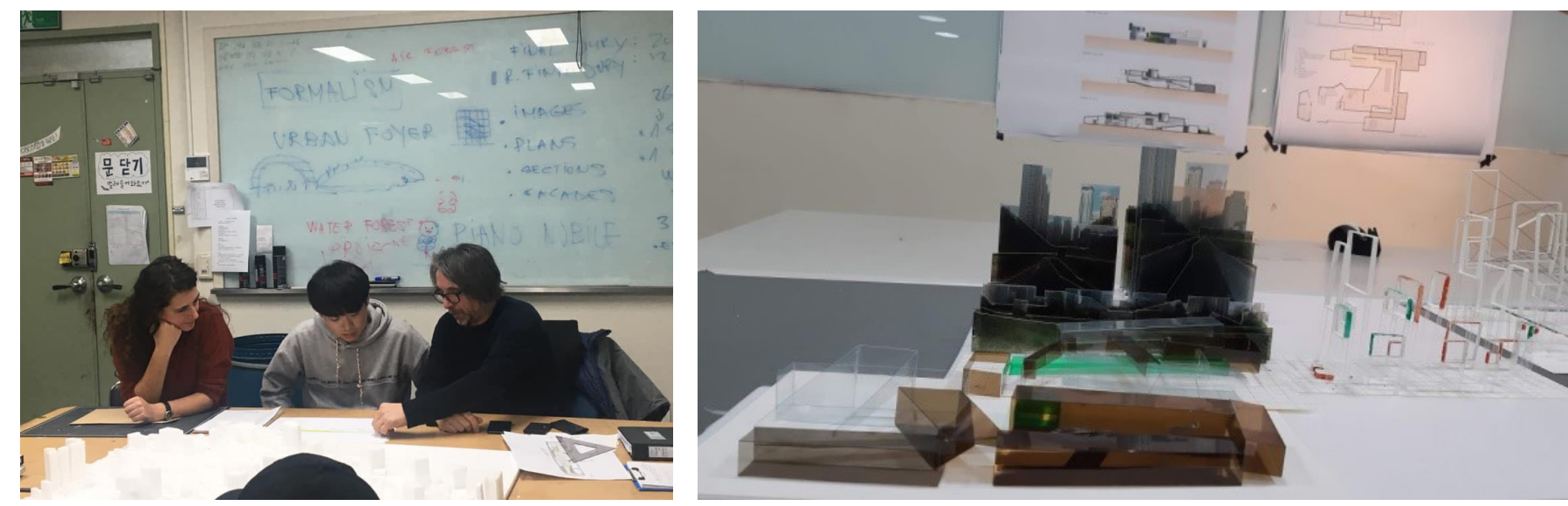

Fig. 7. Atelierul de proiectare este principalul spațiu de lucru al studenților.

Fig. 8. Analiza de sit și concept, machete prezentate la judecata intermediară și la cea finală. îndrumător arh. Jeewon Park.

rezultatul final. De asemenea, materialul prezentat la jurizarea finală denotă o capacitate de sinteză bine antrenată, un demers conștient și asumat care reflectă în mare măsura conceptul pe care și l-au propus (Fig. 9). Îmi răsună încă în minte discuția cu una dintre studente la jurizarea finală: după o pledoarie a juriului despre valoarea proiectului final și a căutărilor ei de pe parcurs, a răspuns, total asumat și afectat, că nu este mulțumită de proiectul ei, deoarece spre deosebire de colegii ei, ea nu a reușit să-și urmeze ideea și conceptul inițial și nu a putut controla demersul până la capăt. Ca atare, în ciuda aprecierilor juriului a rămas „studenta cea mai puțin zâmbitoare” a zilei.

Fig. 9. Machete de pe parcursul proiectului prezentate la jurizarea finală. Indrumător arh. Jeewon Park.

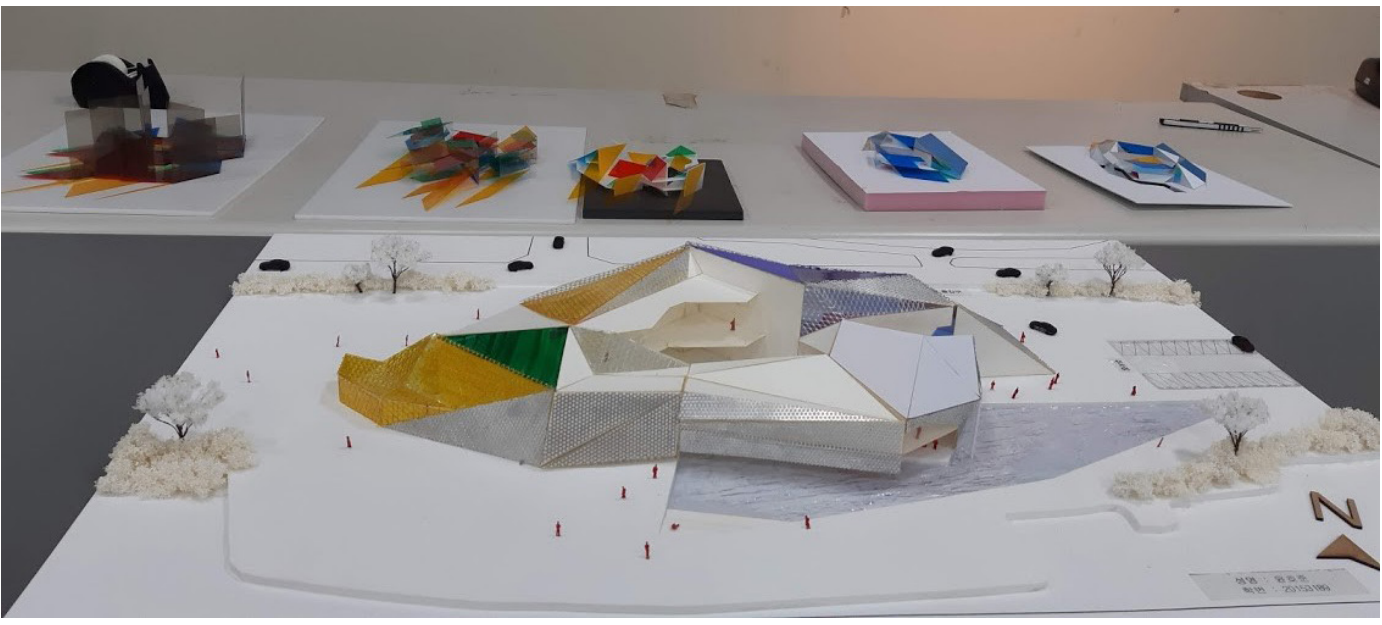


Din discuțiile cu ceilalți îndrumători rezultă că aceștia sunt „mână de fier” în ceea ce privește exigențele față de studenți. Se lucrează pe machetă aproape la fiecare atelier. Observarea și discutarea permanentă a machetelor succesive este unul dintre atuurile îndrumării în atelierele coreene. De altfel, calitatea și cantitatea materialelor/machetelor prezentate la jurizarea finală a anului III a fost impresionantă, comparabilă cu nivelul diplomelor de la noi. (Fig. 10, 11.)
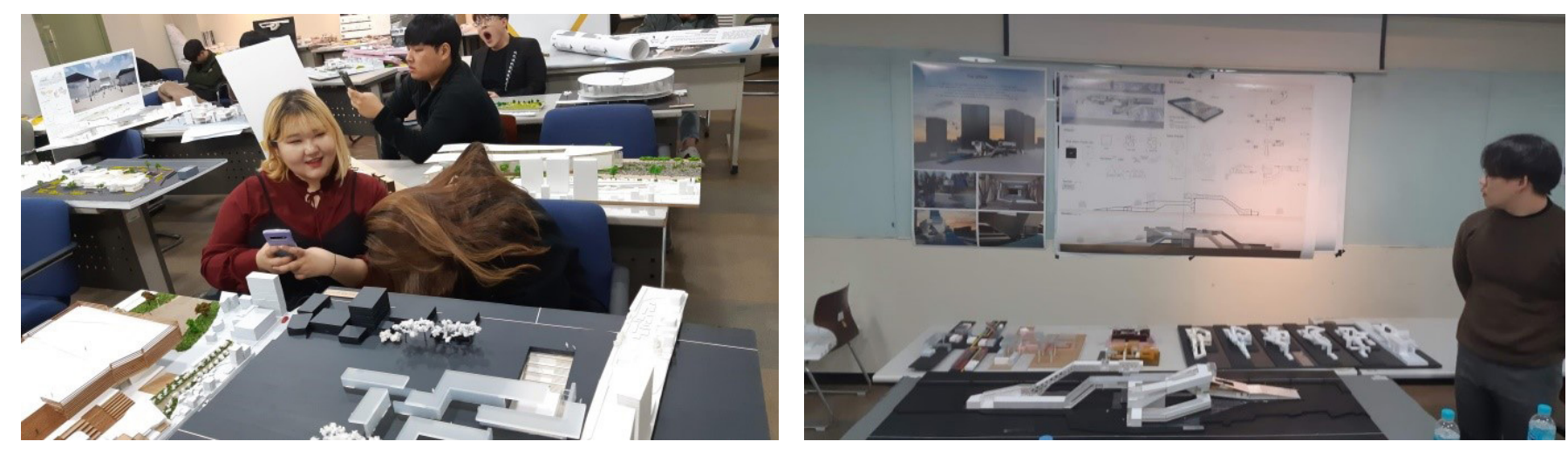

Fig. 10, 11. Jurizarea proiectelor finale, anul III, arhitectură. Studenți îndrumați de arh. Dan Dinoiu, arh. loana Ardelean, arh. Jeewon Park.

\section{ATELIERUL DE DESIGN INTEGRAT}

Subiectele de lucru ale studenților masteranzi sunt foarte variate și pot include proiectarea azilurilor pentru vârstnici, regândirea programelor de locuire pentru vârstnici sau pentru persoane cu dizabilități, analiza și designul spațiilor de spital (plus clinici, cabinete etc.) pentru o experiență pozitivă cât mai puțin traumatică pentru pacienți și un mediu de lucru mai puțin stresant pentru cadrele medicale, analiza și upgrade-ul unor spații existente, analiza și ierarhizarea fluxurilor în spațiile medicale, signalistica acestor fluxuri prin culoare și semne, studii de culoare și efectul culorii asupra percepției utilizatorilor în designul de interior al spațiilor medicale, aplicații media pentru a facilita parcursul pacientului în interiorul spațiului, designul unor broșuri și materiale vizuale cu indicații în caz de evacuare sau hazard adresate persoanelor vârstnice sau cu dizabilități, designul de cărți pentru suport psihologic pentru dizabilități fizice sau mentale etc.

În cadrul abordării departamentului și a atelierelor, o atenție deosebită se acordă analizei utilizatorilor, toate studiile sau proiectele de cercetare se fundamentează pe culegerea de date despre utilizatori: se realizează interviuri, grile de întrebări și de preferințe, chestionare ce înregistrează și cuantifică feedback-ul utilizatorilor. 
Toate acestea sunt procesate și transpuse operativ în strategia de design, indiferent de specialitate.

\section{FUTURE CONTENT DESIGN}

Una dintre cele mai interesante experiențe pentru mine a fost atelierul Future Content Design, în care am îndrumat la aceeași temă masteranzi din toate specialitățile. Aceștia au asistat la discuții și corecturi în comun și au dezvoltat proiecte individuale în funcție de analiza utilizatorului căruia ii era dedicat proiectul - o tânără cu dizabilități care trebuie să-și trăiască viața în dependență de spații și echipamente dedicate, asemenea unora dintre supraviețuitorii incendiului Colectiv.
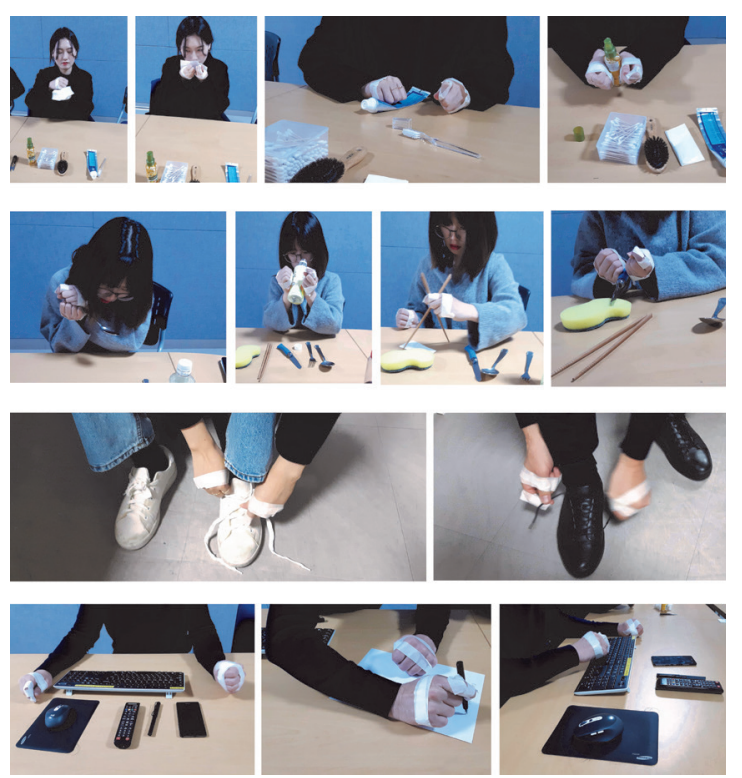

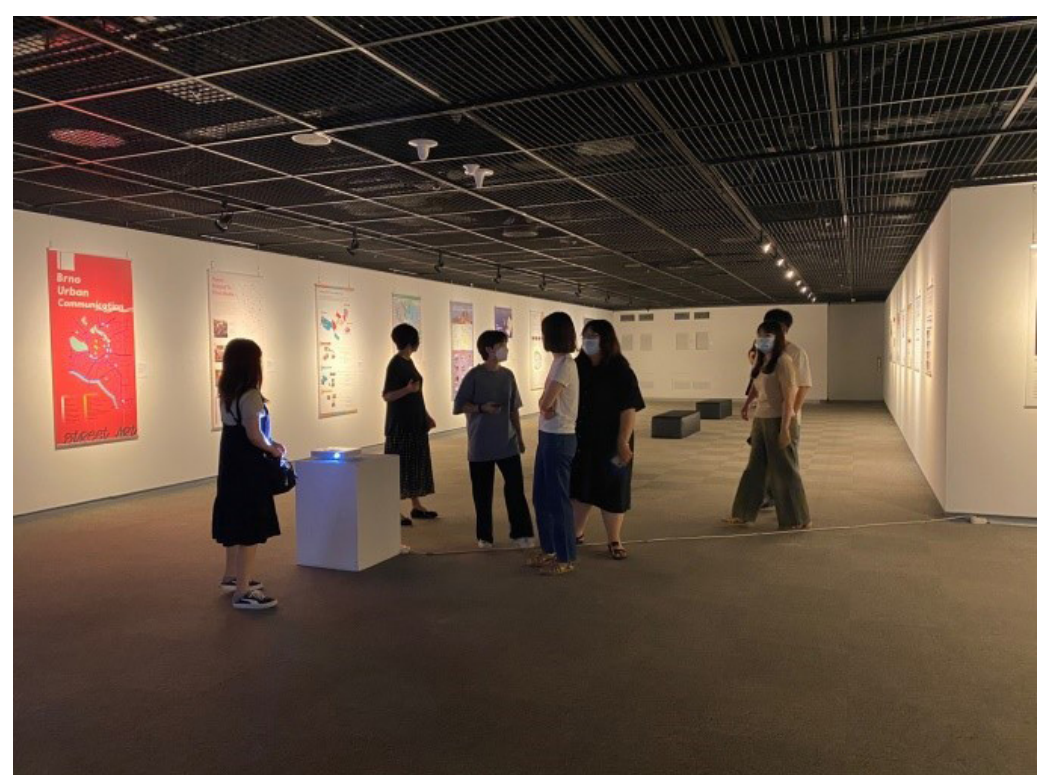

Fig. 12. Analiza utilizatorului în cadrul atelierului de design integrat Future content design, îndrumat de mine.

Fig. 13. Expoziția proiectelor îndrumate în cadrul atelierului de design integrat: Future Content Design.

Unul dintre punctele de pornire a fost experimentul pe care l-am propus studenților (Fig. 12), acela de a se pune în pielea utilizatorului și de a analiza atât posibilitățile cât și provocările la care acesta este supus. De aici mai departe fiecare student a analizat și decis care sunt spațiile și lucrurile vitale de care este nevoie și care pot influența radical starea fizică și mentală a personajului studiat și au dezvoltat sub îndrumarea 
mea proiecte precum: reinventarea locuinței (bucătărie, baie - spații umede, în care în general nu poți opera purtând o proteză a membrelor) și a spațiilor de lucru necesare pe termen lung pentru o persoană tânără cu dizabilități, la designul mouse-ului care devine mănușă pentru mâinile cu degete amputate și până la designul de obiecte interactive, cu rol de companion sau gardian la designul unei cărți de suport psihologic pentru trauma suferită de utilizator.

Rezultatul proiectului din acest atelier a făcut subiectul unui catalog și al unei întregi secțiuni din expoziția 2020 Internațional Exchange Exhibition for Healthcare Design, realizată în colaborare cu Universitatea Masaryk din Cehia, expoziție ce a avut loc în iunie 2020, în cadrul Yunseul Art and Design Center (Fig. 13).

\section{CURSURILE}

În Coreea, durata unui curs este de 3 ore și, în mod surprinzător, cursurile sunt bazate pe procesul de predare-ascultare. Majoritatea covârșitoare a cursurilor nu sunt interactive și echivalează cu conținutul și greutatea unei conferințe, fapt confirmat din toate părțile (verificări cu alți colegi). Normele culturale și sociale, firea discretă, contribuie și ele la o anumită distanță între studenți și profesor.

Subiectul cursului face parte din programa departamentului, dar structura cursului, obiectivele și cerințele impuse studenților sunt la latitudinea profesorului.

Tematica cursurilor pe care le-am susținut a fost următoarea:

Universal Space Design: am analizat și discutat proiecte realizate în arhitectura contemporană europeană, punând în evidență conceptele și strategiile de design din spatele acestora. Aceasta a fost o cerință explicită din partea departamentului. Complementar, am discutat, analizat și comparat proiecte variate destinate azilurilor pentru vârstnici, centrelor de tratament, clinicilor și centrelor rezidențiale pentru persoane cu dizabilități fizice sau mentale, în acord cu direcția de studiu a departamentului, atingând detalii ce țin de toate specialitățile de design, de program și de scheme funcționale.

Users Analysis: o cerință explicită a fost aceea de a discuta și analiza provocările vârstei a treia și a categoriilor de utilizatori cu dizabilități sau vulnerabilități, cu exemple dintre cele mai variate despre implicațiile în strategia de design, abordări, metode și noi tehnologii prin care proiectarea spațiilor, designul de produs sau cel vizual pot contribui la ameliorarea condițiilor de locuire și tratament cât și la bunăstarea utilizatorilor. 
Healthcare Space Design: am discutat proiecte construite dar și studii despre viitorul spațiilor medicale, despre upgrade-ul spitalului de la mașinăria perfect funcțională la un spațiu al vindecării și al experiențelor mai puțin stresante, despre mixitatea și hibridizarea funcțională ce poate schimba interfața dintre spital și pacienți. Tematica a inclus de asemenea centrele pentru vârstnici, pentru categoriile defavorizate sau pentru minori cu vulnerabilități.

Notarea studenților se face în sistem digital, prezența este de asemenea direct înregistrată în sistem de către fiecare student în parte și reprezintă un procentaj din nota finală, alături de evaluarea „atitudinii” studentului la curs cât și evaluarea proiectului sau lucrării predate. Procentul în care aceste evaluări se combină este la latitudinea profesorului.

\section{CONCLUZII}

Coreea consumă foarte mult design iar acest fapt face să existe și foarte multe lucruri redundante sau excesiv abordate în detrimentul altora. Orașele generice au o aparență dezamăgitoare din punct de vedere al expresiei arhitecturii, însă marile dezvoltări de proiecte de locuire au calități peste așteptări mai ales la nivel urbanistic și de conformare a apartamentelor. De asemenea, sunt foarte interesante proiectele mai mici și punctuale ale arhitecților coreeni. Acestea reflectă perfect o expresie contemporană proaspătă și originală cât și sensibilitatea și performanța culturii coreene. Peste toate acestea se suprapune arhitectura starurilor care este foarte convingătoare în contextul coreean.

Coreea de Sud este o țară performantă și cu mari ambiții de a fi lider în noua revoluție tehnologică. Resursele și strategiile din domeniul educației și cercetării nu pot fi egalate de multe țări precum nici cererea internă pe care o populație de peste 50 milioane de locuitori o generează în aceste domenii. Metropolele coreene sunt niște structuri foarte interesante, în continuă dinamică și concurență, iar universitățile urmează aceeași dinamică. De la scara (mică) la care am activat rămâne însă relevantă determinarea celor implicați și perseverența spre performanță.

Sensibilitatea studenților și fluența cu care își abordează proiectele rămâne pentru mine cea mai plăcută revelație din experiența ultimului an. 0 alta este disciplina firească a coreenilor.

În rest, impresia finală este desigur un caleidoscop de fragmente și experiențe ce depind în mare măsură de ochiul privitorului. 